\title{
Introduction to the Minitrack « IT Governance and its Mechanisms »
}

\author{
Wim Van Grembergen \\ University of Antwerp - Antwerp Management School \\ Wim.vangrembergen@uantwerpen.be
}

\author{
Steven De Haes \\ University of Antwerp - Antwerp Management School \\ steven.dehaes@uantwerpen.be
}

To be innovative and competitive in today's global digital economy, organizations have little choice but to invest in information and communication technologies (IT). However, without the proper organizational capabilities and skills to put these digital assets to effective use, organizations are at significant risk of wasting their investments and missing key opportunities for growth and competitiveness.

Against this context, the "IT governance and its mechanisms" research mini-track focuses on the design and implementation of organizational capabilities and e-leadership skills required to be successful in digital innovation and transformation journeys.

Since 2001, we are chairing this "IT Governance and its mechanisms" research track at HICSS, in order to advance research and practice in this area. Already with a tradition of more than 15 years, the research track focuses on the organizational challenges of governing and managing the digital assets and enterprise . In this knowledge area, the emphasis is on how organizations enable both business and IT people to execute their responsibilities in support of business/IT alignment and the creation of business value from IT-enabled investments. [1]

This research track is part of our activities within the IT Alignment and Governance Research Institute (ITAG) of the University of Antwerp and Antwerp Management School. Our aim is to develop state-ofthe-art concepts, models and theories that help organizations to generate more value out of IT enabled investments while managing its business risks. ITAG wants to be an international point of reference that creates, distributes and applies innovative research that is grounded in science and rooted in practice.

The 2019 edition of the HICSS mini-track "IT governance and its mechanisms" is reporting on new and innovative insights that are on the research agenda of the knowledge area. We would like to thank all contributing authors to our research track and look forward to receiving new research submissions next year.

Three general themes can be identified throughout this year's contributions. Firstly, two contributions address the need for organizations to move towards a more agile way of working which has become imperative due to the world's rapid digitization. The authors propose different ways of adopting such agility. Secondly, a specific focus on the top-level of the organization is provided, with a discussion on the evolution of the position of the Chief Information Officer (CIO) and a study of the role of the board of directors in governing IT. Lastly, an in-depth discussion is provided on the topic of business and IT alignment through a co-evolutionary perspective.

Below, you will find an overview of the titles and authors of the 2019 edition of our research track, including the abstracts.

We look forward to discussing these topics with you further at the conference, and receiving your contributions of new innovative work in the future. 


\begin{tabular}{|l|l|}
\hline $\begin{array}{l}\text { Board Engagement in IT } \\
\text { Governance: Opening Up the } \\
\text { Black Box of IT Oversight } \\
\text { Committees at Board Level }\end{array}$ & $\begin{array}{l}\text { Laura Caluwe, Steven } \\
\text { De Haes }\end{array}$ \\
\hline $\begin{array}{l}\text { How the West was Lost: } \\
\text { Chief Information Officers } \\
\text { and the Forgotten Battle of } \\
\text { Jurisdictional Control }\end{array}$ & $\begin{array}{l}\text { Johan Magnusson, Erik } \\
\text { Högberg, Hampus } \\
\text { Sjöman }\end{array}$ \\
\hline $\begin{array}{l}\text { IT Governance and Its Agile } \\
\text { Dimensions }\end{array}$ & $\begin{array}{l}\text { Sulejman Vejseli, } \\
\text { Alexander Rossmann, } \\
\text { Thomas Connolly, }\end{array}$ \\
\hline
\end{tabular}

Board Engagement in IT Governance: Opening Up the Black Box of IT Oversight Committees at Board Level

Researchers and practitioners seem to agree on the importance of boards of directors engaging in IT governance. Yet, only a minority of boards around the globe are taking up accountability for governing IT, pointing towards a knowing-doing gap. Efforts have been made to close this gap by creating implementation guidelines for this type of engagement. One of the most frequently mentioned guidelines is the implementation of an IT oversight or similar committee at board level. However, research shows that few boards have established such a committee, which might be caused by the lack of detailed guidance on the workings and role of such committees. This paper discusses the case of the University of Antwerp that has established two IT oversight committees at board level. We demonstrate how IT oversight committees can be established and how they fit into the role of the board with regard to IT governance.

\section{How the West was Lost: Chief Information Officers and the Forgotten Battle of Jurisdictional Control}

Recent research has highlighted the potential downfall of the role and profession of Chief Information Officer (CIO). As the top executive responsible for IT in an organization, this role has gone through several shifts since its advent in the 1980's. This study addresses how the role has evolved, and, how it will evolve in the years to come. The study utilizes a combination of structured literature review and 19 interviews, informed by Abbott's systems of professions perspective. The study explores the battleground for jurisdictional control and discusses potential avenues for research to better aid our understanding of how the professional role of CIO may be studied in times of digitalization.

\begin{tabular}{|l|l|}
\hline $\begin{array}{l}\text { A process model for public } \\
\text { sector IT management to } \\
\text { answer the needs of digital } \\
\text { transformation }\end{array}$ & $\begin{array}{l}\text { Maija Ylinen, Samuli } \\
\text { Pekkola }\end{array}$ \\
\hline $\begin{array}{l}\text { A Co-evolutionary } \\
\text { Perspective on Business and } \\
\begin{array}{l}\text { IT Alignment: A Review and } \\
\text { Research Agenda }\end{array}\end{array}$ & $\begin{array}{l}\text { Mengmeng Zhang, } \\
\text { Honghui Chen, Kalle }\end{array}$ \\
\hline
\end{tabular}

\section{IT Governance and Its Agile Dimensions}

Information technology (IT) plays an essential role in organizational innovation adoption. As such, IT governance (ITG) is paramount in accompanying IT to allow innovation. However, the traditional concept of ITG to control the formulation and implementation of IT strategy is not fully equipped to deal with the current changes occurring in the digital age. Today's ITG needs an agile approach that can respond to changing dynamics. Consequently, companies are relying heavily on agile strategies to secure better company performance. This paper aims to clarify how organizations can implement agile ITG. To do so, this study conducted 56 qualitative interviews with professionals from the banking industry to identify agile dimensions within the governance construct. The qualitative evaluation uncovered 46 agile governance elements. Moreover, these dimensions were rated by 29 experts to identify the most effective ones. This led to the identification of six structure elements, eight processes, and eight relational mechanisms.

A process model for public sector IT management to answer the needs of digital transformation

While organizations get prepared for digitalization so must their IT departments. This means the IT departments have to increase their agility to respond varying requests from different groups of users, increase infrastructure flexibility, and improve the utilization of the current resources. To answer these needs, traditional approaches and modes of IT management are often insufficient. We consequently propose a process model for public sector IT departments so that they can adjust their operations to the requirements by the digitalization efforts, such as smart cities and digital transformation. Our focus is especially in improving the IT development process within the organization, i.e. how the IT department can better respond to the 
needs of business units. Our findings show that adjustments for digitalization require changes both in management and daily operations. Moreover, changes should not be done only internally in the IT department but the other parts of the organization should be involved.

A Co-evolutionary Perspective on Business and IT Alignment: A Review and Research Agenda

Business and IT Alignment (BITA) has received a growing attention during the last decades. Due to increasing environmental and organizational complexities, a co-evolutionary perspective has emerged recently to understand and to control the dynamics in BITA. The Business and IT Coevolution (BITC) aims to coordinate business and IT through continuous adaptation and learning. A series of BITC studies have been conducted since the 2000s. This study provides an organized review of the current knowledge of this area. Its contribution is threefold: 1) organizing extant literature on BITC, 2) revealing knowledge gaps, and 3) proposing a research agenda.

\section{References}

[1] De Haes, S., Van Grembergen,W, Enterprise Governance of IT: Achieving Alignment and Value, Springer, 2015 